\title{
НАДАННЯ МЕДСЕСТРИНСЬКОЇ ДОПОМОГИ ПАЛІАТИВНИМ ПАЦІЄНТАМ ХОСПІСНОГО ВІДДІЛЕННЯ ЧЕРНІГІВСЬКОЇ МІСЬКОЇ ЛІКАРНІ № 4 ЧЕРНІГІВСЬКОЇ МІСЬКОЇ РАДИ
}

\author{
Н. I. Рега, С. О. Ястремська, М. М. Мішкіна \\ Тернопільський національний медичний університет \\ імені І. Я. Горбачевського МОЗ Украӥни
}

У роботі наведено структуру захворюваності та причини смертності пацієнтів хоспісного відділення Чернігівської міської лікарні № 4 Чернігівської міської ради, оцінено інтенсивність хронічного больового синдрому в цих хворих та запропоновано рекомендації для покращення надання медсестринської допомоги паліативним пацієнтам.

\section{NURSING CARE FOR PALIATIVE PATIENTS IN HOSPICE DEPARTMENT, CHERNIHIV CITY HOSPITAL NO. 4, GHERNIHIV CITY COUNCIL}

\author{
N. I. Rega, S. O. Yastremska, M. M. Mishkina \\ I. Horbachevsky Ternopil National Medical University
}

\begin{abstract}
The article represents the structure of morbidity patterns and the causes of mortality in patients of hospice department, Chernihiv City Hospital No. 4, Chernihiv City Council. It is estimated the intensity of chronic pain syndrome in these patients and the recommendations for improvement of nursing care of palliative patients are offered.
\end{abstract}

Вступ. Паліативна допомога (ПД) - це підхід, який дозволяє покращити якість життя пацієнтів із невиліковними захворюваннями та допомогти членам їхніх родин шляхом запобігання та полегшення страждань невиліковно хворої людини (визначення ВOО3, 2002 р.). Головною метою ПД є підтримка якості життя на фінальній стадії, максимальне полегшення фізичних та моральних страждань пацієнта та його близьких, а також збереження людської гідності пацієнта. ПД можна надавати разом із допомогою, спрямованою на одужання, але ії мета не виліковування, а піклування [1].

Основні засади надання Пд:

- полегшення болю та інших симптомів невиліковної хвороби;

- надання підтримки, яка допомагає жити максимально творчо;

- покращення якості життя.

Відповідно до сучасних міжнародних підходів та концепцій, паліативна медицина повинна бути (c) Н. І. Рега, С. О. Ястремська, М. М. Мішкіна, 2019 невід'ємною, інтегрованою складовою медичного обслуговування та соціальної опіки. Декларація ВООЗ (1990) та Барселонська декларація (1996) закликають усі держави світу включити ПД у структуру національних систем охорони здоров'я [2, 3]. За характеристикою медико-демографічної ситуації, Україна належить до демографічно старих країн світу. Частка населення віком 60 років і старших становить понад 11 млн осіб (або 23,9 \%), кількість людей, старших за 75 років, дорівнює близько 3,5 млн осіб, і їх кількість буде невпинно зростати. Постаріння населення в Україні, як і в інших країнах Європи, призводить до збільшення кількості людей, які помирають у старечому віці від хронічних соматичних хвороб, що супроводжуються тяжкими фізичними та психічними розладами, і потребують паліативної та хоспісної допомоги [4]. Щорічно в Україні реєструють близько 160 тис. хворих на онкологічні захворювання, а понад 90 тис. пацієнтів помирають від цієї недуги. Уже до 2020 р. прогнозують збільшення захворюваності на онкологічні захворювання до 200 тис. Окрім того, 
члени сімей паліативних пацієнтів також потребують професійної допомоги. Невиліковно хвора людина спричиняє зниження якості життя всієї родини, стає причиною тяжких психологічних, соціальних та економічних розладів функціонування, зубожіння та руйнування сім'ї. Якщо до кількості паліативних хворих додати ще по 1-2 родичі, які доглядають за ними, то виходить, що близько 1,5 млн осіб щороку потребують паліативної та хоспісної допомоги, адже вони страждають від фізичного та морального болю, бо безсилі допомогти рідній людині. У всьому світі спостерігають тенденцію до збільшення кількості хворих із поширеними формами злоякісних новоутворень. За даними ВООЗ, щоденно у світі від болю страждають 3,5 млн онкохворих. Кожного року майже півмільйона осіб в Україні можуть потребувати послуг пДдля полегшення симптомів хвороб, що загрожують життю [5]. До них належать хвороби системи кровообігу, в тому числі хронічні хвороби серця (майже 489 тис. смертей на рік), рак (100 тис.), респіраторні хвороби (28 тис.), туберкульоз (10 тис.), неврологічні розлади, у тому числі хвороба Альцгеймера (6 500) та ВІЛ/СНІД (близько 2 500) [6]. Саме тому ПД є важливою складовою системи охорони здоров'я та соціального захисту громадян України, вона забезпечує реалізацію прав людини на гідне завершення життя та максимальне зменшення болю і страждань. ПД - це комплекс медичних, соціальних, психологічних та духовних заходів, спрямованих на поліпшення якості життя пацієнтів, які мають невиліковну хворобу та обмежений прогноз життя, а також членів їхніх сімей. Головні завдання ПД - позбавлення від болю, усунення або зменшення розладів життєдіяльності та інших тяжких проявів хвороби, а також догляд, психологічна, соціальна та духовна допомога пацієнту та його рідним як в умовах спеціалізованого медично-соціального закладу - хоспісу, так і вдома $[7,8]$.

В останні роки одним із пріоритетних напрямків медицини $є$ проблема поліпшення якості життя інкурабельних хворих. Вимоги сьогодення у держави та суспільства до ефективності професійної діяльності медичних сестер зростають. Система медичної допомоги в нашій державі та в багатьох інших країнах світу налаштована так, що основні ресурси спрямовуються на спеціалізоване лікування і одужання хворого. Якщо вилікувати цього хворого не вдається, то людина виявляється фактично поза системою надання спеціалізованої медичної допомоги.
Враховуючи вищевикладене, метою роботи стало вивчення структури захворюваності та причин смертності пацієнтів хоспісного відділення Чернігівської міської лікарні № 4 Чернігівської міської ради та оцінка інтенсивності хронічного больового синдрому (ХБС) у цих хворих.

Основна частина. Проведено оцінку структури паліативних пацієнтів хоспісного відділення Чернігівської міської лікарні № 4 Чернігівської міської ради протягом 2015-2017 рр.

Хоспісне відділення розраховане на 50 ліжок.

у 2015 р. у відділенні проліковано 182 особи. Померло 73 пацієнти (40,1%). Структуру захворювань (\%) наведено на рисунку 1.

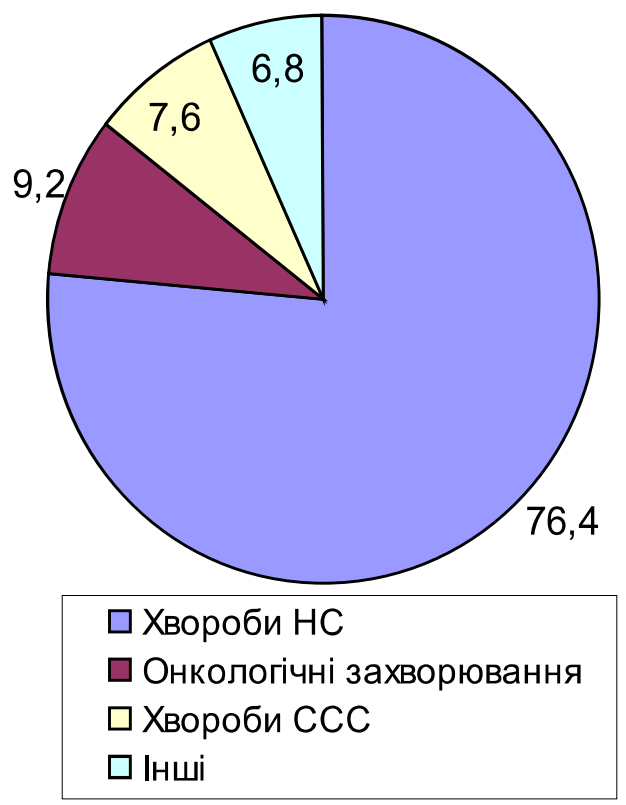

PUс. 1. Структура захворювань (\%) пацієнтів хоспісного відділення у 2015 р.

За даними рисунка 1, переважно у хоспісі перебували пацієнти з неврологічними захворюваннями.

у 2016 р. у відділенні проліковано 187 осіб. Померло 82 пацієнти (43,9 \%). Структуру захворювань (\%) наведено на рисунку 2.

За даними рисунка 2, переважно у хоспісі перебували пацієнти з неврологічними захворюваннями. Порівняно із 2016 р., має місце чіткіша спеціалізація хоспісного відділення.

У 2017 р. у відділенні проліковано 166 осіб. Померло 69 пацієнтів (41,6 \%). Структуру захворювань (\%) наведено на рисунку 3.

За даними рисунка 3, переважно у хоспісі перебували пацієнти з неврологічними захворюваннями. 

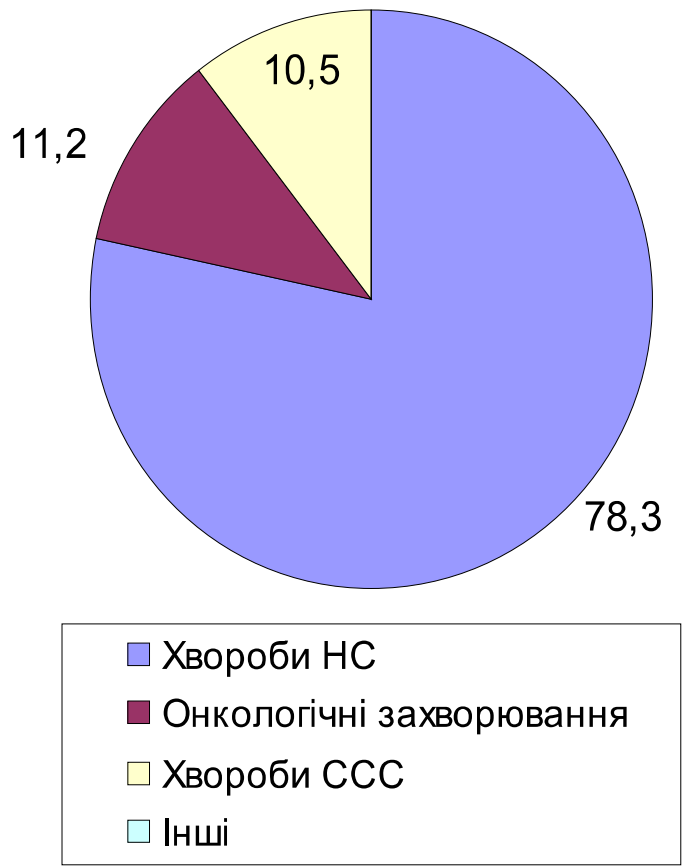

PUC. 2. Структура захворювань (\%) пацієнтів хоспісного відділення у 2016 р.

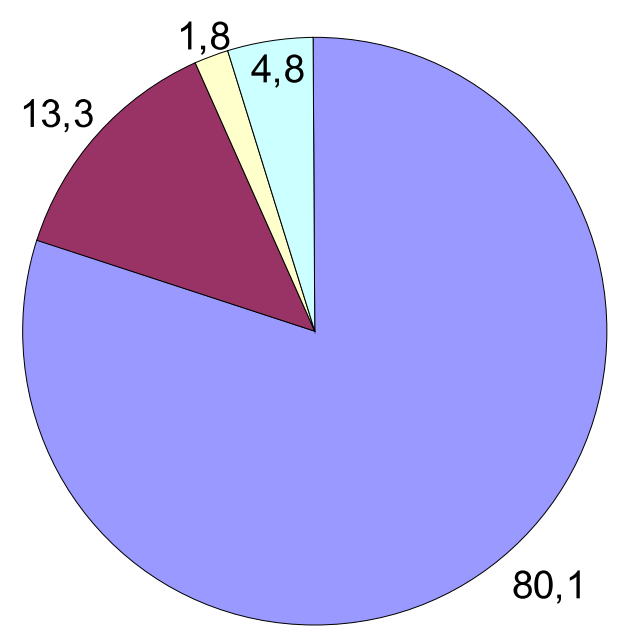

$\square$ Хвороби НС

口 Онкологічні захворюв ання

$\square$ Хвороби ССС

$\square$ Інші

Рис. 3. Структура захворювань (\%) пацієнтів хоспісного відділення у 2017 р.

Порівняно із попередніми роками, $є$ тенденція до зростання питомої частки онкологічних захворювань та зменшення кількості пацієнтів із хворобами серцево-судинної системи.

Проведено оцінку хронічного больового синдрому (ХБС) в паліативних пацієнтів хоспісного відділення
Чернігівської міської лікарні № 4 Чернігівської міської ради протягом 2018-2017 рр.

В опитуванні взяли участь 112 пацієнтів (68 жінок та 44 чоловіки), які отримували паліативне лікування. Як діагностичний інструментарій було використано структуроване клініко-психологічне інтерв'ю. Статистичну обробку проводили з використанням методів описової статистики у MS Excel v. 8.0.3. Результати вираженості БС залежно від етапу лікувального процесу наведено на рисунку 4.

БС не виявляли лише у 7,0 \% хворих, слабкий біль відчували 12,6 \%, помірний - 23,1 \%, тоді як сильний у 57,3 \% онкологічних пацієнтів (рис. 4).

Суттєвих відмінностей у структурі БС поміж жінок та чоловіків установлено не було. Таким чином, серед

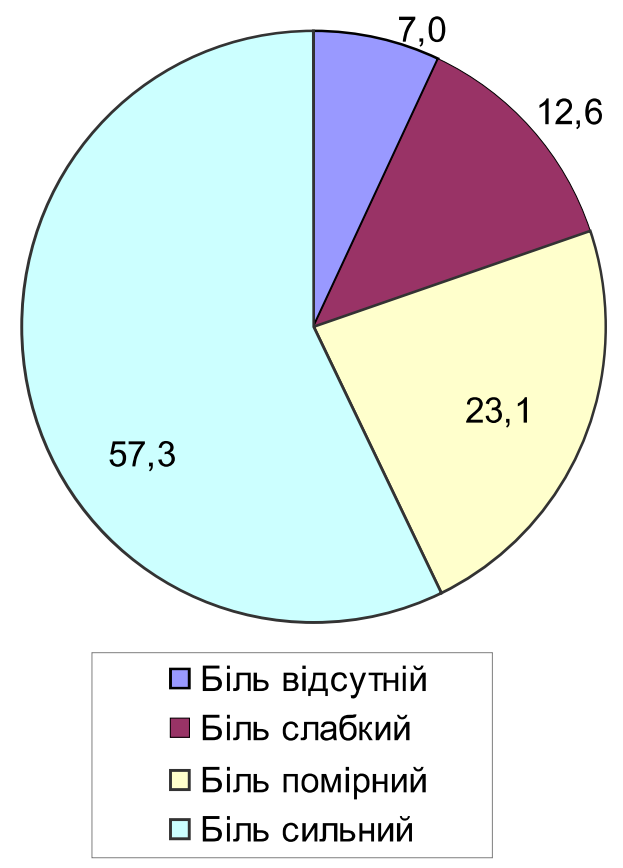

Рис. 4. Поділ паліативних пацієнтів (\%) за вираженістю больового синдрому.

онкологічних пацієнтів біль був досить поширеним симптомом, його частота й вираженість зростали 3 перебігом захворювання, що корелює із результатами багатьох досліджень [9-12].

Наявність болю в онкологічних хворих супроводжувалася медичними, психологічними та психосоціальними наслідками. Онкологічні пацієнти зазначали, що поява постійного болює одним із провідних мотивуючих чинників звернення за медичною допомогою. Локалізація, інтенсивність, періодичність як основні характеристики ХБС були критеріями для лікарської діагностики та самодіагностики стану. Наявність болю стала причиною обмеження у житті 
пацієнтів, які стосувалися фізичного навантаження, активності, дієти. Серед хворих на паліативному етапі лікування у 57,3 \% діагностували сильний ХБС. Основними психологічними наслідками ХБС були порушення у психоемоційному стані онкологічних пацієнтів. У 74,6 \% онкохворих спостерігали страх онкологічного болю різного ступеня - від нечастих думок до нав'язливого стану. Пацієнти з болем (65,1 \% усіх обстежених) вказували на зниження настрою в $100 \%$ випадків, тривогу, пов'язану з очікуванням появи чергового нападу чи посилення больових відчуттів, - у 73,5 \%, обмеження активності - в 67,7 \%, дратівливість - у 58,4 \%, емоційну лабільність - у 49,0\%.

Пацієнтам із ХБС була властива больова поведінка: комплекс поведінкових вербальних (скарги, зітхання, стони) та невербальних проявів при гострому чи хронічному болю (протибольова поза, дотики чи стискання болючого місця, обмеження активності, приймання ліків, гримаса болю), що відповідає даним багатьох досліджень [13-15].

Для зниження больових відчуттів 89,4 \% онкологічних пацієнтів приймали протибольові засоби, тоді як 10,6 \% - не користувалися ліками, що пояснювали незначною інтенсивністю БС та небажанням негативно діяти на організм «хімічними анальгетиками».

\section{СПИСОК ЛІТЕРАТУРИ}

1. Паліативна і хоспісна медицина: концепція, складові, розвиток в Україні (за даними наукової літератури) / В. М. Князевич, 3. М. Митник, Ю. І. Губський // Україна. Здоров'я нації. - 2009. - № 3 (11). - С. 55-63.

2. Про утворення Інституту паліативної та хоспісної медицини МОЗ України : наказ МОЗ України від 24 липня 2008 р. № 159-0.

3. Government and NGOs cooperation to improve of palliative care specialists' education and training in Ukraine / A. Tsarenko, Yu. Gubskiy, V. Tchaykovska [et al.] // 11th Congress of the European Association for Palliative Care. 7 - 10.05.2009. Abstracts. Austria. Vienna, 2009. - P. 149.

4. Організаційні проблеми надання допомоги інкурабельним хворим / Є. Й. Москвяк, Б. Т. Білинський // Лікарська справа. - 2007. - № 4. - С. 86-91.

5. Співпраця громадських організацій та державних установ у підготовці кадрів для служби паліативної та хоспісної допомоги / А. В. Царенко, Ю. І. Губський, В. Г. Сердюк та ін. // Х з'їзд ВУлТ. 24-27.09.2009. Українські медичні вісті. - 2009. - Т. 8, № 1-4 (68-71). - С. 377.
Психосоціальні наслідки БС включали погіршення якості життя у 98,2 \% випадків, зниження щоденної здатності до самообслуговування - в 93,7\%, соціальної адаптації - у 86,4 \%, наростання напруженості у міжособистісній взаємодії - у 59,8\%.

Висновки. 1. Переважно у хоспісному відділенні Чернігівської міської лікарні № 4 Чернігівської міської ради протягом 2015-2017 рр. перебували пацієнти з неврологічними захворюваннями. Спостерігали тенденцію до зростання питомої частки онкологічних захворювань та зменшення кількості пацієнтів із хворобами серцево-судинної системи.

2. Біль - частий прояв онкологічних захворювань. Його частота й вираженість зростає з перебігом захворювання. Він чинить багатогранний вплив на функціонування хворого та має значущі медичні, психологічні та психосоціальні наслідки. Для медичного персоналу важливими є навички поінформованості щодо поведінки пацієнта з болем для поліпшення професійної взаємодії.

3. ХБС не виявляли лише у 7,0 \% хворих, слабкий біль відчували 12,6 \%, помірний - 23,1 \%, тоді як сильний -у 57,3 \% онкологічних пацієнтів, що свідчить про потребу в адекватній оцінці болю та адекватному знеболюванні.

6. Opieka paliatywna na Ukrainie: osiagniecia i perspektywy / Yu. Gubsky, W. Serdiuk, S. Martyniuk-Gres [et al.] // Clinical and Experimental Letters. - 2007. - Vol. 48, Suppl. B. - P. 23-24.

7. Callaway M. Advancing palliative care: The public health perspective. Foreword / M. Callaway, F. D. Ferris // J. Pain Symptom Management. - 2007. - Vol. 33 (5). - P. 483-485.

8. Stjernsward J. The Public Health Strategy for Palliative Care / J. Stjernsward, K. M. Foley, F. D. Ferris // J. Pain Symptom Management. - 2007. - Vol. 33 (5). - P. 486-493.

9. Мухаровська І. Р. Медико-психологічні аспекти больового синдрому в онкологічних хворих на етапах лікувального процесу / І. Р. Мухаровська // Медична психологія. - 2016. - № 4. - С. 32-36.

10. Основні аспекти адекватного знеболення онкологічних хворих / О. М. Клюсов, О. В. Калачов, Г. О. Вакуленко [та ін.] // Практикуючий лікар. - 2012. - № 1. - С. 12-14.

11. Лісецький В. А. Знеболення онкологічних хворих на дому і в хоспісі / В. А. Лісецький, Г. П. Олійніченко, О. В. Калачов // Острые и неотложные состояния в практике врача. - 2010. - № 4. - С. 42-43. 
12. Голубев В. Л. Психологические установки пациента и переживание боли / В. Л. Голубев, А. Б. Данилов // Hейponews. - 2010. - № 8 (27). - С. 25.

13. Pain in 1,000 womentreated for breast cancer: a prospective study of pain sensitivity and postoperative pain / M. A. Kaunisto, R. Jokela, M. Tallgren [et al.] // Anesthesiology. - 2013. - Vol. 119 (6). - P. 1410-1421.
14. Jain P. Prevalence of acute neuropathic pain after cancersurgery: A prospective study / P. Jain, D. Padole, S. Bakshi // Indian J. Anaesth. 2014. - Vol. 58 (1). - P. 36-42.

15. Rajmohan V. Psychiatric morbidity, pain perception, and functional status of chronic pain patients in palliative care / V. Rajmohan, S. K. Kumar // Indian J. Palliat. Care. 2013. - Vol. 19 (3). - P. 146-151.

Отримано 26.08.19 